\title{
КИССПЕПТИН ПЛАЗМЫ КРОВИ ПРИ ЗАДЕРЖКЕ СТАРТА ПУБЕРТАТА
}

\author{
Плаксина А.О., Саракаева Л.Р., Юхлина Ю.Н., Никитина И.Л. \\ ФГБУ «НМИЦ им. В.А. Алмазова» Минздрава России, Санкт-Петербург \\ ФГБУ «Национальный медицинский исследовательский центр им. В.А. Алмазова» Минздрава РФ, Санкт-Петербург
}

АКТУАЛЬНОСТЬ: установлено, что в иерархии репродуктивной оси системе кисспептина отводится ведущая роль в центральной регуляции старта пубертата.

ЦЕЛЬ: изучение динамики плазменного уровня кисспептина у мальчиков с задержкой полового развития.

ПАЦИЕНТЫ И МЕТОДЫ: в исследование включены 75 мальчиков, рандомизированных на три группы. Первую (основную) группу составили 22 ребенка старше 14 лет с задержкой старта пубертата. Группы контроля: группа №2 - 25 мальчиков старше 14 лет с физиологическим развитием пубертата (Таннер IV-V), группа №3 - 28 мальчиков младше 10 лет, не имеющих старт пубертата в физиологически допустимые сроки (Таннер І). Уровень кисспептина в крови определяли методом ИФА с помощью специфического набора (CloudClone Corp., США). Статистический анализ проводили с помощью пакета программ Microsoft Excel 2010 для Windows.

РЕзУЛЬТАТЫ: медиана кисспептина крови в основной группе составила 31,2 пг/мл и была значимо выше, чем в обеих контрольных группах $(p<0,05)$. Данный показатель в группах контроля не различался и составил 13,8 пг/мл (p>0,05). По данным анализа распределения под кривой (ROC) уровня кисспептина в основной и контрольных группах, было установлено пороговое значение кисспептина крови 16,9 пг/мл, которое с высокой специфичностью (92\%) и чувствительностью (73\%) может быть использовано в качестве критерия патологического развития пубертата ( $<<0,0001)$.

Выводы: при физиологическом течении полового развития вне зависимости от стадии пубертата содержание кисспептина плазмы было низким, тогда как при задержке старта пубертата отмечалось значимое повышение данного показателя. Вероятно, повышение уровня кисспептина в крови развивается вследствие ослабления его биологической активности или десенситизации кисспептиновых рецепторов. Установлено пороговое значение уровня кисспептина крови, которое может быть рекомендовано в качестве диагностического, биохимического маркера задержки центральных механизмов реактивации гонадной оси при клинических симптомах задержки старта пубертата у мальчиков. 